\title{
Assessing marine spatial planning governmentality
}

\author{
Wesley Flannery ${ }^{1}$ (D) $\cdot$ Ben McAteer $^{1}$
}

Received: 9 September 2019 / Accepted: 23 April 2020 / Published online: 2 May 2020

(C) The Author(s) 2020

\begin{abstract}
Marine spatial planning (MSP) is advanced by its champions as an impartial and rational process that can address complex management issues. We argue that MSP is not innately rational and that it problematises marine issues in specific ways, often reflecting hegemonic agendas. The illusion of impartial rationality in MSP is derived from governmentalities that appear progressive but serve elite interests. By understanding the creation of governmentalities, we can design more equitable planning processes. We conceptualise governmentalities as consisting of problematisations, rationalities and governance technologies, and assess England's first marine plans to understand how specific governmentalities de-radicalise MSP. We find that progressive framings of MSP outcomes, such as enhanced well-being, are deployed by the government to garner early support for MSP. These elements, however, become regressively problematised in later planning phases, where they are framed by the government as being difficult to achieve and are pushed into future iterations of the process. Eviscerating progressive elements from the planning process clears the way for the government to focus on implementing a neoliberal form of MSP. Efforts to foster radical MSP must pay attention to the emergence of governmentalities, how they travel through time/space and be cognisant of where difference can be inserted into planning processes. Achieving progressive MSP will require the creation of a political frontier early in the process, which cannot be passed until pathways for progressive socio-environmental outcomes have been established; advocacy for disenfranchised groups; broadening MSP evaluations to account for unintended impacts; and the monitoring of progressive objectives.
\end{abstract}

Keywords Marine spatial planning $\cdot$ Governmentality $\cdot$ Marine governance $\cdot$ Stakeholder participation $\cdot$ Transformative governance

\section{Introduction}

Marine spatial planning (MSP) has been quickly adopted by national governments as the solution to an array of issues, yet questions remain about its capacity to reform unsustainable marine management (Ritchie and Ellis 2010; Jones et al. 2016; Smith and Jentoft 2017; Smith 2018; Tafon et al. 2018; Saunders et al. 2019; Gissi et al. 2019). While other novel marine management concepts, such as various ecosystem-focused approaches (e.g. Ecosystem Services, Ecosystem-based Management, etc.) have been slowly

Wesley Flannery

w.flannery@qub.ac.uk

Ben McAteer

bmcateer06@qub.ac.uk

1 School of Natural and Built Environment, Queen's University Belfast, Belfast, Northern Ireland adopted, MSP has rapidly attained a preeminent position within marine governance discourses and practices (Toonen and van Tatenhove 2013). The perceived neutrality and accessibility of MSP enables a range of actors to inscribe their values onto it, increasing its appeal and simultaneously hiding the role of power in shaping MSP processes. We argue that power is exercised in MSP through the creation of specific governmentalities that reflect the interests of elite stakeholders and co-opts others into believing that MSP will serve their interests. By understanding how these governmentalities are created we can resist them and recapture the radical and progressive potential of MSP.

The avid adoption of MSP is partially due to it being more accessible to non-specialists than ecosystem-focused approaches, which have been critiqued for being exclusionary and privileging specific forms of knowledge (Díaz et al. 2018; Stefansson et al. 2019). Although MSP is often labelled as another ecosystem-focused approach (Foley et al. 2010) it is, in practice, less orientated towards environmental issues than core ecosystem management concepts. We suggest that the 
broad appeal of MSP is due to spatial planning appearing to be a relatively value-neutral concept when compared to ecosystem approaches, which may be perceived as having inherent biases towards achieving environmental objectives. Spatial planning appears to be more neutral and easier to mobilise as a governace mechanism than, for example, an ecosystem services approach. Dominant policy discourses have also adopted asocial and apolitical framings to advance MSP as an inherently "rational" means of achieving balanced management in the future (Tafon 2018). The conceptual simplicity, malleability and supposed rationality of spatial planning contribute to the broad appeal of MSP while masking the fact that it is a complex socio-political activity. Although it may be a familiar and relatively understandable concept, spatial planning is rarely a neutral, unbiased process and should, instead, be viewed as a power-laden arena wherein actors compete to imprint their agenda on specific spaces (Tafon 2018, 2019).

The simplistic framing of MSP as a neutral or win-win process (see White et al. 2012) in dominant MSP discourses is based on an uncritical engagement with the power dynamics that shape space. With little attention paid to these dynamics, MSP is advanced by its promotors as a transformative governance approach with the capacity to fundamentally change how we govern the ocean (Ehler and Douvere 2009). MSP promotors frame it as a mechanism that can reform marine governance through the "rational organization of the use of marine space" (Douvere 2008, p.766), without acknowledging that powerful interests and structures may prevent the implementation of progressive transformations. The transformative narratives surrounding MSP largely ignore the inhibitory role power plays in nullifying transitions or in unjustly skewing transformations (Blythe et al. 2018; Kelly et al. 2018; Bennett et al. 2019). Rather than acknowledging how power shapes planning processes, MSP is framed by its most ardent supporters as a rational and logical process that sits above power (Flannery et al. 2019).

Inattention to power issues has diminished the capacity of MSP to transform marine governance. Although it has been rapidly adopted worldwide (Jay et al. 2013), there is a growing body of literature illustrating MSP's failure to deliver on its transformative potential (Ritchie and Ellis 2010; Jones et al. 2016; Smith and Jentoft 2017; Smith 2018; Tafon et al. 2018; Fairbanks et al. 2019). Many of these evaluations explicitly or implicitly highlight power-related issues as critical deficiencies of MSP initiatives. Failing to address issues of power within MSP has been blamed for, inter alia, maintaining the agendas of dominant actors through the use of empty participatory rhetoric (Ritchie and Ellis 2010; Smith and Jentoft 2017; Tafon 2018), the development of weak objectives that fail to address critical marine problems (Jones et al. 2016; Sander 2018) and the deployment of technocraticmanagerial and post-political forms of governance that favour dominant or well-established interests (Flannery et al. 2018; Smith and Jentoft 2017; Aschenbrenner and Winder 2019). These evaluations raise questions about MSP's capacity to address long-standing governance issues, the fairness and legitimacy of its participatory processes (Smith 2018; Tafon 2019; Kelly et al. 2019), and illustrate how it may not precipitate transformative governance and do little more than preserve the status quo (Flannery et al. 2018).

MSP should not be dismissed as an inherently regressive process as it has vast transformative potential. For example, MSP can account for cumulative negative impacts on marine ecosystems (Foley et al. 2010); address conflict and other issues that have arisen from sectoral and fragmented marine governance and the industrialisation of the ocean (Ehler and Douvere 2009); and address the democratic deficit in marine management (Flannery et al. 2018). What is clear from academic evaluations of MSP is that it has been implemented through practices that have stifled its transformative capacity. We urgently need to (re)capture MSP's radical possibilities before it loses all claims to be a legitimate form of governance (Flannery et al. 2016). Although there are various critiques of MSP, many fail to answer why it has not achieved its promise or to provide alternative pathways through which it can realise its progressive capacity (Fairbanks et al. 2018, Kelly et al. 2019; Tafon 2019 being particularly notable exceptions). There is, therefore, a fundamental need to critically assess how power is exercised in MSP initiatives to advance practices that nullify its radical and transformative capacity and, following Boucquey et al. (2019), explore how MSP can be made different.

Drawing on Johnsen (2017), we view the introduction of MSP as an attempt to redefine the state-environment-society governance nexus. The introduction of MSP creates opportunities for actors to reimagine this nexus. Although this nexus is shaped by power, we argue that this power is not enacted through explicit forms of domination but, rather, through the creation of MSP governmentalities. Governmentalities are social processes that aspire to influence the actions, subjectivities, and behaviours of others to achieve desired ends without recourse to repressive power (Huxley 2008). Governmentalities are powerful processes through which actors seek to shape the actions, values or norms of free individuals (Foucault 1982) to establish "the right disposition of things, arranged so as to lead to a suitable end" (Foucault 2007 p. 96). Governmentality is not the coercive power exercised by states and other powerful actors through domination, repression or other forms of violence, but is, rather, a more deceptive and complex form of power. Foucault regards power as being concerned with the "management of possibilities" and is more about the capacity to "structure the (possible) actions of others" than outright domination (Foucault 2003, p.138). In this sense, governmentalities are not solely regressive and can lead to progressive social and environmental outcomes (Fletcher 2010). The influence of 
governmentality is often unnoticed, has unconscious impacts, is taken for granted and can appear innocuous. The form of power created by governmentalities relates to the regimes of practices that are formed "by institutions, procedures, analyses, and reflections, the calculations and tactics" that create the "mentalities" that seek to shape how subjects think and act (Foucault 1991b, p. 102). For example, the audit and ecoaccreditation culture in fisheries advances neoliberal governmentalities that turn fishers into eco-entrepreneurs with, sometimes, deleterious social and community consequences (Foley et al. 2018; Bresnihan 2019). By understanding how these governmentalities are created we can resist regressive forms of MSP and work towards more radical and transformative approaches.

This paper develops and applies a framework for assessing MSP governmentalities. Analysing power through a governmentality lens does not seek to identify sources or locations of power, nor does it attempt to interrogate the legitimacy which underpins the execution of power (Dean 1999). Rather, it is concerned with assessing the actual art and conduct of governing and identifying how regimes of practices are established (Dreyfus and Rabinow 2014). We frame governmentalities as consisting of three key components, problematisations, rationalities and governance technologies, and address common critiques of governmentality scholarship by explicitly including time/space in our approach. The next section develops our MSP governmentality analytical framework. This is followed by an account of our study area, the east coast of England, and our methodological approach. The subsequent section presents key findings, illustrating how MSP becomes de-radicalised during the planning process, leading to a discussion of the MSP governmentality in England and how it, and other MSP processes, can be made different.

\section{MSP governmentality}

Through governmentalities, the actions of free subjects can be guided or conducted, not by an omnipotent powerholder, but via the establishment of different regimes of practices. Regimes of practices are the combination of activities that seek to address a problem in a specific way, without these practices necessarily being part of formal programmes (Stephan et al. 2013). For example, a regime of practice is forming around marine conservation (Stafford and Jones 2019) that focuses attention on addressing individual behaviour (e.g. reducing consumption of single-use plastic) while ignoring large-scale structural issues (e.g. reforming governance regimes, reducing consumption, etc.). These practices are not explicitly part of formal governmental programmes and are often being instilled through informal mechanisms, such as media campaigns (Stafford and Jones 2019).
Regimes of practices seek to define governance problems and their solutions and attempts to embed these as accepted truths through the development of rationalities and governing technologies that shape how actors behave. Governing, in this Foucauldian sense, is understood as the creation of truths that define problems, desired ends, and the procedures that will be implemented to achieve them. These truths become embedded in dominant regimes of practices so that the "chosen" option appears to be the rational choice. The production and implementation of these truths are the fundamental mechanisms through which governmentalities become established. This occurs through three inter-related governance processes, which form the core aspects of our analytical framework: problematisations, rationalities, and technologies.

\section{Problematisations}

Within the governmentality perspective, governance is viewed as a problematising activity (Rose and Miller 1992). Governance problems are not self-evident truths but are socially constructed through problematising processes. Problematisation is the process of framing a phenomenon as both a problem and as an object of governance (Hutter et al. 2014). Through the production of truths, problematisations define who and what should be governed and how and by whom it should be done (Dean 1999; Rose 1996; Lemke 2001). As such, problematisations do not simply represent concrete contemporary issues, they refer to the creative work that legitimises something as a problem in need of intervention, while simultaneously creating the conditions under which certain answers can be constructed (Lemke 2019). A focus on the production of problems is not to deny that contemporary issues exist but, rather, acknowledges that these have been framed in particular ways through the construction of certain "truths" and that they should be viewed as both current and historically contingent (Lemke 2019). For example, Blue Growth governmentalities seek to problematise the issue of stakeholder and sectoral conflict that arises from rapidly expanding maritime industries in ways that will not restrict this expansion or empower marginalised groups to resist it (Barbesgaard 2018; Cohen et al. 2019; Schutter and Hicks 2019; Satizábal et al. 2020). Within these governmentalities, conflict is often problematised as being a product of uncoordinated, sectoral management approaches, not as a result of industrial expansion itself. By problematising conflict in this way, Blue Growth governmentalities frame the issue being governed (conflict) as poor management and something to be resolved by reforming the state's approach (e.g. introducing more integrated forms of management), justifying the continued expansion of marine industrialisation and largely ignoring the urgent need for degrowth thinking in marine governance (Hadjimichael 2018). 
Furthermore, problematisations produce fields of visibility (Dean 1999) in the sense that they foreground certain aspects of "reality" while hiding others, so that an issue becomes governable in the manner that an actor desires (Taylor 2011). For example, ecosystem services approaches can be used to narrowly focus on "ecosystems that consist only of services that already take the commodity form" (Robertson 2012, p. 397), reducing the complexity of human-environment relations to those that can be managed through a narrow range of econometric methods. We also view problematisation processes as being duplicitous, whereby several aspects may be problematised as being equally important to solving an issue, particularly to gain broad support, but only discrete elements of the problematisation will be taken forward. For example, a lack of stakeholder participation and poor data are often problematised as concurrent and entwined issues to be resolved within MSP, yet there are examples of perfunctory participation approaches being conducted in parallel with detailed data collection processes (Flannery et al. 2018).

\section{Rationalities}

The strength of problematisations to dominate governance issues is dependent on the rationalities that they deploy to convince governance subjects about the veracity of their truth claims. Analysing governmentalities enables us to understand how actors both portray their framings of phenomena to other groups and how they seek to shape the responses of these groups (Hillier 2015). As actors are free to react to problematisations as they see fit, problematisations must be rationalised to them. Rationalities are the discourses that seek to provide justifications (moral, ethical, scientific, etc.) for specific problematisations (Rose and Miller 1992). To understand governmentalities is, therefore, to see how actors govern through the production of truth (Foucault 1991a). These truths are asserted through claims of particular knowledge of the problem to be addressed (e.g. knowledge of the economy or the environment) to gain legitimate control over how issues will be governed. By appearing to make issues knowable and thinkable, truths are used to rationalise the governance of phenomena in particular ways (Rose and Miller 1992). In China, for example, economic rationality dominates discourses on marine governance and justifies the rapid expansion of maritime industries (Choi 2017).

Although rationalities seek to provide justifications for governmentalities they should not be viewed as transcendental reasonings, even when they make moral or ethical claims. Rationalities are not pure, neutral forms of knowledge or logic that simply represent reality, but are, instead, socially produced rationalisations of problems and solutions (Lemke 2002). The power of rationalities functions through the creation of discourses that seek to justify specific actions through truth claims and/or through appeals to reason (Flyvberg 1998).
For example, rationalities related to the ill-defined notion of the "public good" are often mobilised to justify controversial or inequitable urban planning decisions that only benefit elite actors (Murphy and Fox-Rogers 2015).

Rather than being unbiased reasonings for actions, rationalities are contingent on and influenced by, specific power relations (Flyvbjerg and Richardson 2002). Although rationalities are products of these power relations, they are not exercised through explicit commands to action but seek to influence conduct in more nuanced ways, predominantly by shaping the discourse around an issue. The aim of these discourses is to both legitimise specific governance actions and to render "reality" governable in precise ways (Lemke 2002). For example, geo-spatial rationalities are mobilised in MSP discourses to reduce reality to uncomplex, asocial renderings that make the marine environment appear governable through mapping and zoning approaches (Smith and Brennan 2012), often failing to capture complex socio-environmental aspects of these areas (St. Martin and Hall-Arber 2008; Peters and Steinberg 2019; Trouillet 2019).

\section{Technologies}

As they are discursive and focused on the politics of truth, rationalities, in and of themselves, do not guarantee the achievement of specific governmental objectives. To be effective, governmentalities must be successful in constructing the technical means to give practical effect to these rationalities. Technologies are the material aspects of governmentalities and refer "to the practices and devices through which political rationalities are operationalized" (Merlingen 2011, p. 153). Governance actors must use technologies if governmentalities are to achieve their desired ends (Dean 1999). In other words, problematisation and rationalisation discourses must be materialised as practices (Lemke 2019). Governmentality technologies consist of programmes, calculations, techniques, apparatuses, documents and procedures that seek to give effect to governmental ambitions (Rose and Miller 1992). It is through these technologies that problematisations and rationalities are deployed (Rose and Miller 1992). For example, stakeholder participation can be deployed as a technology to realise a governmental aim of responsibilisation, wherein the state divests itself of responsibility for addressing an issue, for example, flooding, by "empowering" the public (Moon et al. 2017).

The relationship between rationalities and technologies also flows in the opposite direction, with specific practices being rationalised as they emerge and their usefulness to governmentalities becomes apparent (Dean 1999). Technologies are both mechanisms that stabilise and enact specific rationalities and are devices that reimagine policy interpretations as they encounter reality and users (Rap and Wester 2017). Technologies, therefore, have a double-sided nature. Technologies function both to operationalise 
rationalities and become new components of governmentalities that will also need to be rationalised as their utility becomes apparent. Recognising the dual nature of technologies acknowledges that governance subjects are not passive actors and may repurpose technologies as they pass through time/space.

\section{Time/space}

Some scholars analysing governmentalities have been critiqued for adopting instrumentalist and functionalist perspectives (Rap and Wester 2017); assuming that programmes will unproblematically achieve their desired effects (Dupont and Pearce 2001) or that governmentalities are completed projects (O'Malley et al. 1997); and for naively conducting research in a manner that suggests that subjects unthinkingly respond as desired to governmentalities (Rap and Wester 2017). The application of Foucault's approach in this manner is incorrect, as it cannot be presumed that power always realises its ambitions (McKee 2009). People are active subjects capable of resisting or repurposing governmental technologies (Dupont and Pearce 2001) and governmentalities can go astray when they meet their target audience (Rutherford 2007).

To avoid these errors, it is important to recognise the centrality of genealogy to the governmentality perspective, the role that contingency plays in shaping governmentalities and to acknowledge that they may change through time or when they come into contact with different people or spaces (Lemke 2019). Furthermore, governmentalities should not be viewed as linear progressions from problematisation to realisation (i.e. that problematisations rest on the production of particular rationalities which leads to specific technologies). The relationships between problematisations, rationalities and technologies are more complex than the direct transfer of an idea into practice and it is important to recognise that governmentalities change over time and as they transverse different spaces. For example, the creation of governmentalities solely at a national scale will seldom achieve their aims due to the spatial disconnect between national state governance mechanisms and localised practices (Hannah 2000; Fairbanks 2019). To be fully realised, the logic of governmentalities must, therefore, cascade down through spatial hierarchies, often entailing the development of new relationships between governmentality components, and raising multiple opportunities for them to be reformed, co-opted or challenged. Including a time/space element in our analytical framework recognises that governmentalities are not delivered as fully realised projects, but are disputed, reformed, and recalibrated over time and are unceasingly re-articulated through the most amenable channels (Rutherford 2007).

The alteration of governmentalities as they pass through time/space should not be viewed narrowly as the dilution of a programme as it comes into contact with reality, but, rather, highlights that governmentalities may need to be realised through a variety of strategies and adapted to diverse contexts (Lemke 2002). Governmentalities take unpredictable courses as they encounter "effective opposition and resistance to them; the impact of unforeseen circumstances and mistakes; the outcomes of struggles between conflicting interpretations and unexpected contradictions" (Hutchinson and O'Malley 2019 p.71). Assessing the genealogy of governmentalities, therefore, focuses our attention less on the actual "control" of subjects and more on the attempts to create the conditions to control over time (Hutchinson and O'Malley 2019) while also acknowledging that programmes are in a constant state of becoming and are often resisted (Rutherford 2007).

\section{Methodology and study site}

We selected England as our case study as it is one of the first countries to develop, implement and assess statutory MSP. ${ }^{1}$ English MSP is a good example through which to explore how specific MSP governmentalities arise. Like other early adopters, MSP in England has been largely driven by the emergence of new spatially fixed marine uses (e.g. wind farms), has been implemented by a neoliberal government and entailed the development of a new agency and new legislation.

The first plans in England were published by the Marine Management Organisation (MMO) in 2014 and cover the East Inshore and Offshore areas (see Fig. 1). The East Inshore area spans the coastline from Flamborough Head to Felixstowe and encompasses the sea area from the mean high-water mark to 12 nautical miles. The East Offshore area extends from 12 nautical miles to the limit of the UK's Exclusive Economic Zone. The two plans were published together as The East Inshore and East Offshore Marine Plans (HM Government, 2014) and are referred to from hereon as the East Marine Plans.

Our study consists of a thematic analysis of planning documents related to the development and assessment of these plans. Focusing solely on documents as our data source allows us to be faithful to Foucault's governmentality approach, wherein the aim is to identify attempts to create conditions to control rather than to discover if control was exercised (Hutchinson and O'Malley 2019). Based on the literature review above, we adopted a deductive thematic framework, consisting of problematisations, rationalities, and technologies, to analyse the East Marine Plans and associated documents. Documents analysed include the following: $U K$ Marine Policy Statement (DEFRA 2011); The East Inshore and East Offshore Marine Plans (DEFRA 2014); Evidence and Issues Overview Report (MMO 2014); Statement of Participation (MMO 2015); Three-year report on the East

\footnotetext{
${ }^{1}$ In UK policy and legislation MSP is referred to as marine planning.
} 

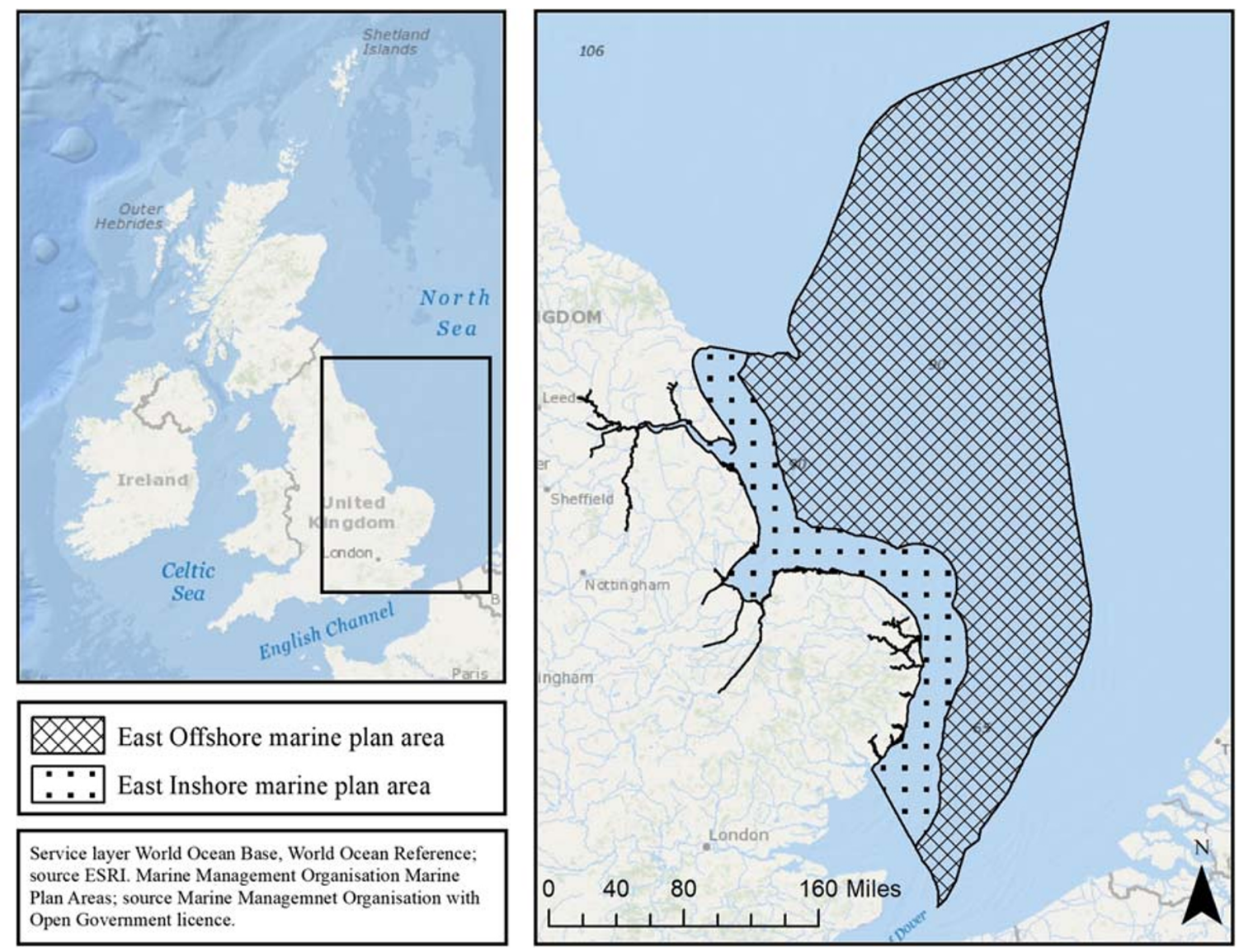

Fig. 1 The East Inshore and Offshore planning areas

Marine Plans (DEFRA 2017). We also analysed 35 speeches made by ministers and government officials concerning these plans or MSP in general (see Supplementary Material for a list of all documents and speeches that were analysed).

To capture how MSP governmentality travels through time/space, we divided the planning process into four distinct phases: normative, strategic, operational, and monitoring (Flannery 2011). We define the normative phase as mainly being the early part of the planning process, and largely concerned with defining the desired ends and the principles and ideals that will be implemented to achieve them (Smith 1982). The normative phase is often related to the development of national-level policies or programmes. The strategic phase focuses on selecting an approach from the range of options that could be pursued to achieve programme objectives (Smith 1982). The strategic phase tends to be a mix of national and local level processes. The operational phase centres around the implementation of the selected strategy (Smith 1982) and is usually focused on the local level. The monitoring phase focuses on assessing the success, or otherwise, of a programme and can be either a national or local level assessment, or a mixture of both. Each of these phases represents a staging point in the planning process (see Table 1 for an example of these phases). We recognize that these phases are difficult to delimitate and that planning processes

Table 1 Four phases of planning

\begin{tabular}{|c|c|c|c|c|}
\hline Planning phases & Normative & Strategic & Operational & Monitoring \\
\hline Primary focus of phase & Define desired ends & $\begin{array}{l}\text { Choose the instruments to } \\
\text { achieve ends }\end{array}$ & $\begin{array}{l}\text { Develop implementing } \\
\text { instruments }\end{array}$ & Assess progress \\
\hline $\begin{array}{l}\text { Fisheries management } \\
\text { example }\end{array}$ & $\begin{array}{l}\text { Increased fish stocks is defined } \\
\text { as the desired ends }\end{array}$ & $\begin{array}{l}\text { Decision made whether to } \\
\text { implement MPAs; reducethe } \\
\text { number of fishing licences; tax } \\
\text { fish products; etc. Decision } \\
\text { made to implement MPAs. }\end{array}$ & $\begin{array}{l}\text { Portal for collecting MPAdata } \\
\text { produced; stakeholder } \\
\text { participatory methods rolled } \\
\text { out; final MPA designations } \\
\text { mapped and implemented }\end{array}$ & $\begin{array}{l}\text { Monitoring } \\
\text { programme of fish } \\
\text { stocks implemented; } \\
\text { socio-economic im- } \\
\text { pacts of MPAs } \\
\text { assessed; etc. }\end{array}$ \\
\hline
\end{tabular}


may move back and forth between them or that sometimes two of them may overlap or run in parallel, but they provide broad temporospatial categories through which we can capture the evolution of governmentalities.

\section{Findings}

Findings are presented below as they relate to each phase of the planning process. During the normative phase, MSP is portrayed as a radical and progressive approach that will have broad societal and environmental befits. Our findings, however, illustrate that MSP becomes de-radicalised through a process of re-problematising progressive rationalities and technologies as they move through the four planning phases. For example, progressive rationalities (e.g. best available science) and technologies (e.g. stakeholder participation) become regressively problematised by the government at each subsequent planning phase, while neoliberal ambitions become the main governance objects of the MSP governmentality. As MSP moves through the planning phases, progressive reforms are managed out of the process by the government so that, by and large, the status quo remains intact and the proposed environmental and societal benefits become by-products, at best, of a neoliberal planning regime.

\section{Normative phase: the need for radical governance reform}

\section{Problematisations}

During the normative phase, the state-environment-society nexus is problematised by the government as requiring radical transformation (DEFRA 2010). The state's approach to marine management is pronounced as being inefficient, the environment is framed as being under severe pressure, and society is presented as insufficiently benefiting from the exploitation of marine resources. Reforming the marine governance regime is problematised by the government as a collective project that will benefit all, particularly coastal populations and marine industries, and enhance environmental sustainability. The government's broad problematisation of governance reform focuses on the ineffective nature of existing management practices and how overhauling these will serve the interests of the environment, communities and industry (DEFRA 2010).

The government frames the introduction of MSP as a way for the state to address long-standing inefficiencies emanating from sectoral and fragment governance approaches. For example, the government advances the introduction of MSP as an opportunity to address these issues through the development of a radical new approach to marine management that will lead to consistent decision-making (DEFRA 2010). The introduction of MSP is framed by Parliamentary Under-Secretary of State at the Department for the Environment, Food and Rural Affairs, Richard Benyon, as enabling better and more informed decision-making and long-term spatial thinking:

we have the power to change the way we use our marine spaces and resources, for now and for the future. To make better, more informed and long-term decisions on what we want in our seas, when and where (Benyon 2010).

The marine environment is acknowledged by the government as being highly pressurised, with this likely to increase in the future and that this will need to be addressed through improved management practices. Acknowledging increased environmental pressure does not, however, lead the government to problematise this issue in a manner that would limit industrial expansion. As illustrated below, instigating better management practices does not mean the government is seeking to introduce plan-led development and a system of tradeoffs aimed at reducing environmental pressures. Instead, better management here relates to reducing the bureaucratic burden on industries, providing certainty for investors and speeding up consenting processes (DEFRA 2011).

The government also seeks to problematise societal aspects of the state-environment-society nexus during this phase, but this is done in a vague manner. Society is framed as insufficiently benefiting from the marine environment and maritime industry:

[Potential development] considerations must be integrated with social considerations on equality, community cohesion, wellbeing and health (DEFRA 2011, p. 16).

During the normative stage, the government argues that all those who have a stake in the marine environment will have an input into MSP (DEFRA 2011). Society is also being viewed as a vital source of data and experience that can inform the reimagining of the governance regime. The government, therefore, attempts to position MSP as a means of both ensuring society is a major benefactor of new marine development and as a way of addressing the democratic deficit in marine governance.

\section{Rationalities}

The government's rationalities for reform are also very broad and ambitious and appear to be mobilised to convince governance subjects that the government is adopting a radical approach to MSP. Concern for the environment and society are used as central rationalities for reforming marine governance. For example, one of the main rationalities underpinning reform of marine governance is that it will be informed by the development of a rigorous evidence base: 
Our understanding of the marine environment continues to develop through new scientific and socio-economic research and data collection. Sound evidence and monitoring underpins effective marine management and policy development (DEFRA 2011, p. 12).

Despite acknowledging the severity of environmental pressures, reforming the governance regime is framed as favouring continued development and the introduction of MSP is proffered by the government as a means of ensuring this is done in a sustainable manner. By rationalising state reform through a sustainable development lens, the government seeks to provide legitimacy to continued industrial expansion:

Properly planned developments in the marine area can provide environmental and social benefits as well as drive economic development, provide opportunities for investment and generate export and tax revenues. The marine planning system will help to promote these benefits in contributing to the achievement of sustainable development. There will therefore be a presumption in favour of sustainable development in the marine planning system (DEFRA 2011, p. 16).

Although there are data gaps, MSP is advanced by the government as a process through which these can be addressed. MSP is, therefore, rationalised as being both based on best available science and also the process through which any gaps in this knowledge will be addressed, suggesting that a robust data gathering process will form part of the MSP process (DEFRA 2011).

\section{Technologies}

Two technologies of implementing this governmentality are initiated by the government in the normative phase: stakeholder participation, and a focus on community well-being. Meaningful engagement is construed by the government as being a key planning principle, with a broad range of interests viewed as contributing to the realisation of a more sustainable marine future:

Marine planning will define the future uses of our seas in any given area, with the full engagement of all those interested in the marine environment, from local communities to businesses (DEFRA 2010).

The documents produced by the government during the normative stage also frame MSP as contributing to coastal community well-being, equality, community cohesion, and health (DEFRA 2011). As these documents are from the normative phase, they do not seek to actualise these technologies. Instead, these documents should be viewed as the initiation of the technologies that will become manifest in the later phases. What we can note from these documents is that the technologies are ambitious and promise to deliver a range of social outcomes from MSP but are also lacking specificity.

\section{Strategic phase: defending the status quo}

\section{Problematisations}

The socio-ecological rationalities and technologies mobilised by the government during the normative phase would appear to suggest that future industrial expansion would be tempered by environmental protection and concerns regarding societal issues. Historic planning practices, however, illustrate that economic priorities tend to dominate "sustainable development" processes (Wang et al. 2014). In our case study, the emphasis on economic and neoliberal priorities becomes more pronounced in each successive phase of the MSP process, while the progressive elements become problematised themselves, or are framed as issues to be resolved in the future and not as core elements to achieving sustainable development. The dominance placed by the government on economic and neoliberal priorities within the strategic phase is, therefore, accompanied by efforts to depreciate the state's capacity to achieve environmental and social objectives.

During the strategic phase, the government problematises the state-environment-society nexus in ways that erode the radical approach to MSP mapped out during the normative phase. The current management approach continues to be framed by the government as being inefficient, but increasing significance is placed on resolving efficiencies from a narrow economic perspective, particularly reducing the "burden" of regulation on industry. Concurrently, less emphasis is placed on ensuring that a more efficient system delivers on progressive elements (e.g. enhancing coastal well-being). In practice, efficient marine governance becomes narrowly problematised by the government to mean reforming the consenting regime so that it is quicker, less "complex" and responds to the concerns raised by industry (MMO 2014).

In contrast to the manner in which economic objectives become more clearly defined, progressive elements such as rigorous data collection, broad participation, well-being and other benefits that should accrue to coastal communities, become regressively problematised and minimised by the government in terms of their centrality to English MSP. For example, society is problematised as being highly differentiated in terms of its capacity to engage with MSP, with participation being framed as burdensome to a portion of stakeholders and that "some methods of engagement may not be appropriate for all" (MMO 2015, p. 11). Engagement with stakeholders and wider society is still framed by the planning agency as being a core component of MSP, but that it will need to distinguish 
between the capacity of stakeholders to engage (MMO 2014). This framing does not lead the government to instigate a capacity-building programme with under-resourced and overstretched stakeholders. Instead, stakeholder participation becomes problematised itself and framed as something that the government can do differently with various groups, ignoring how this may benefit those with the most resources. Similarly, in documents from the strategic phase, the government acknowledges that there are concerns that coastal communities may not benefit from further economic development in the manner envisaged during the normative phase. This issue is, however, problematised as being something that will be addressed through evidence-gathering processes and resolved through MSP:

Economic benefits of marine development and where they accrue is under scrutiny. Some forms of development are seen as contributing little to economic wellbeing at local level. This will be explored further via our evidence gathering (MMO 2014, p. 8)

\section{Rationalities}

During the strategic phase, the government's rationality for reforming the state's governance approach mainly focuses on the need to address "inefficiencies" in the existing regime. The government rationalises the reformation of the consenting regimes in terms of the certainty it will provide developers and how the new system will aid them to defend their projects against objections:

Marine users should also feel more confident that decisions made on applications for projects will be robust in the face of challenge, provided they are made in accordance with marine plans (MMO 2015, p. 3).

The government cannot be viewed as restructuring the marine governance system solely to benefit economic sectors, and also seeks to rationalise reform by claiming that the certainty that will emanate from MSP will also enhance the wellbeing of disadvantaged communities:

communities, including less well-off areas that will benefit from economic confidence in sustainable development (MMO 2015, p. 5).

Replacing the existing system with MSP is rationalised by referring to the robust data that will underpin the latter and by claiming that it will mirror best practice from elsewhere. During this phase, the MMO highlights the vast range of data collected to date, the issues that have emerged, including evidence gaps. The MMO rationalise this as being a robust database on which to base MSP and that it can underpin the next phase in the planning process:

we have drawn together the range of relevant evidence but also, highlighted the issues that emerged from the evidence. This should inform any discussion of key issues and the next steps in the planning process - helping us to establish a clear vision and objectives for the plan areas (MMO 2014, p. 3).

MSP is rationalised as being effective as it mirrors England's terrestrial planning systems, the best practice credentials of the latter being derived from the length of time it has been in place (MMO 2015), rather than any claim to being effective in delivering well-being or other benefits to disadvantaged communities. The fact that that their approach has been developed through the international exchange of approaches in workshops with representatives from the Netherlands, Belgium, France and the USA is also used by the government to rationalise its effectiveness (MMO 2015).

\section{Technologies}

Enhancing well-being is again activated as a technology by the government during this phase. We view the mobilisation of a well-being narrative here as the emergence of it being used as a co-option technology. Although "well-being" is viewed as being a beneficial outcome of enhanced market and investor certainty, the government does not add any specifics as to how this will be realised in coastal communities. Similarly, the government technology of stakeholder participation is framed in less meaningful and impactful terms, moving towards more tokenistic forms of engagement, such as information sharing, with the public and stakeholders having potentially less direct input into the planning process (MMO 2015). Enhancing well-being and engaging in stakeholder participation are, therefore, less technologies through which the government will deliver progressive MSP objectives and should, instead, be viewed more as co-option procedures that seek to limit meaningful engagement and to convince governance subjects of the value of MSP.

\section{Operational phase: do not rule Britannia!}

\section{Problematisations}

During the operational phase, the government increasingly problematises MSP through post-political framings, which limit stakeholder engagement and the creation of new knowledge and focuses on addressing neoliberal objectives. Tenuous links are made to the radical reformation of marine 
governance envisaged in the normative phase, with progressive objectives (e.g. enhancing coastal well-being) framed by the government as being auxiliary goals that will be realised by achieving economic objectives. Rather than reforming marine governance, the government seeks to cement a form of MSP that focuses solely on the needs of industry and that indirectly benefits the environment and society. The role of the state in MSP moves from being problematised as needing to be reformed to instigate good, environmental planning, to being framed as needing to be transformed to reduce the bureaucratic red tape faced by industries (DEFRA 2014).

The issue of coastal well-being, one of the key mechanisms through which society is framed as benefiting from MSP, is problematised by the government as an ancillary issue that will be achieved through trickle-down economics and actions in policy areas that are outside the MMO's remit. For example, enhancing coastal well-being is narrowly problematised by the government as increasing employment opportunities for coastal populations and, unlike the issue of red tape, no actions are developed to address this issue. Instead, vague commitments are made about ensuring that employment opportunities are created in communities adjacent to the planning area:

the need to ensure that local people can access the jobs being created in and adjacent to the East marine plan areas. It is about helping people into work by supporting development and other activities that create jobs at all skills levels, connected to activities in the marine area (DEFRA 2014, p. 26).

In government documents concerned with the operational phase, progressive elements of previous phases are problematised as being difficult to achieve in these plans and are pushed into the next iteration of the planning process. For example, the use of best available science in the planning process is problematised by the government as a lack of useful knowledge and used to justify less prescriptive policies:

The Marine Management Organisation has collated the best available evidence base to support the development of marine plans, and the process has also highlighted some clear gaps in knowledge (DEFRA 2014, p. 19).

Gaps in the evidence base ... mean that these first marine plans do not include specific spatial or resource allocations for some policies (DEFRA 2014, p. 11).

For most marine sectors, the lack of precise, locally relevant policies means that the MSP process will have little impact on how they are governed and planned. They will, predominantly, need to refer to national-level policies rather than these plans for development guidance, something that has been confirmed in interviews with key stakeholders in another study (Clarke and Flannery 2019).

\section{Rationalities}

The focus on streamlining the licencing process is rationalised in terms of the speed with which developments will be realised, therefore contributing to the economy earlier than they would have in the past (DEFRA 2014). Even though the government recognises key knowledge gaps, the plans are still rationalised in terms of the robustness of their evidence base, which has been reviewed by the planning team before being used in the planning process (DEFRA 2014).

\section{Technologies}

Issues with both the best available science and stakeholder participation become technologies through which the government can mobilise less prescriptive policies. Rather than MSP being the process through which key data gaps and the democratic deficit in marine governance will be addressed, the government marshals these issues as governmental technologies that can ensure that MSP is less radical than originally formulated. Acknowledging that these issues are not addressed within MSP is not framed as a policy failure by the government. Instead, the government uses the cyclical nature of planning as a technology of delay to push these issues into the next iteration of the planning process:

many of the evidence gaps revealed in the East to date also of relevance to other plan areas. This allows for new evidence to be prioritised and commissioned based on necessity and alignment to any key issues as they arise (DEFRA 2014, p. 26).

The lack of key data does not mean that the government will adopt a precautionary approach, and a presumption in favour of development is reiterated during this phase. Furthermore, to ensure that this presumption is fully embedded in the system, the government uses training as a technology to ensure planners comply with this diktat:

The Marine Management Organisation (MMO) will carry out staff training to reinforce awareness of the existing presumption in favour of sustainable development (MMO 2013).

There is an attempt by the government to disguise the clear economic, neoliberal focus of the East Marine Plans. Policies that make insipid reference to increasing employment are used by the government as well-being washing technologies. We describe these polices as well-being washing as they contain 
no implementable actions and lack operational details. For example, the plans contain a policy where "employment benefit" will be the deciding factor when choosing between two competing projects, yet no definition of this benefit is provided, nor does it contain guidance on how this will be measured across projects (DEFRA 2014). The issue of enhancing coastal well-being is, therefore, deployed by the government as a hollow technological procedure, with the aim of legitimising their objectives through a process of well-being washing.

\section{Monitoring: "consistent with anticipated progress"}

\section{Problematisations}

The monitoring phase consists of a very narrow review of the plans' impact. There is no attempt by the government to investigate the unintended impacts of the plans and the review focuses solely on how the plan is achieving its aims. In the progress review, the government frames MSP as progressing as planned and problematises the lack of robust data as the core issue that needs to be addressed. The government reports that data for key social and environmental policies are unavailable and that progress on these is unable to be assessed at this time (DEFRA 2017). The robust evidence base that was rationalised as underpinning the planning process is now framed as a problem to be resolved in the next iteration of the process.

\section{Rationalities}

The government does not, however, wish for the serious data gaps, and the lack of a coherent strategy to address them, to be read as a failure of the monitoring approach. Rather, the monitoring approach is rationalised by the government as being effective and efficient and as being recognised as one of the best approaches in the world. For example, the monitoring process is rationalised as being efficient as relatively little new data were collected to monitor the progress of the plans:

To minimise duplication of effort and make the best use of resources, monitoring drew primarily on other existing environmental, social and economic monitoring programmes, and data readily generated by the MMO (DEFRA 2017, p. 9).

Even though there are large evidence gaps, the government's approach to monitoring is rationalised as being robust as it has been praised in two key reports, one of which was commissioned by the MMO and highlights the need for counterfactual assessments, which were not implemented in the review process, and another that was published before the first review was undertaken, which praised the proposed monitoring approach to be adopted by the MMO:

The MMO's approach to monitoring has been recognised as being among the more advanced examples of integrating [monitoring] considerations (DEFRA 2017, p. 9).

\section{Technologies}

Community well-being and the iterative nature of planning processes are again deployed by the government as convincing and delaying technologies to shape how the plans and monitoring process will be received. Although enhanced well-being cannot be directly attributed to the plans, nor is it clearly defined in the review, the increased personal wellbeing of those living in areas adjacent the plans was used as a monitoring measure. Although the impacts of the plans on this measure are unclear and indirect, at best, it is claimed as being successfully achieved:

Wellbeing measures improved consistently from 2012 to March 2015 ... Areas bordering the east marine plan areas experienced consistently better personal wellbeing than those of England generally. The effect of the East Marine Plans is unclear as the baseline showed this pattern before plans were adopted although direction of travel of this indicator is consistent with objective intent (DEFRA 2017, p. 12).

The government mobilises the iterative cycle of the planning process as a technology to convince governance subjects that things will be better in the future. For example, data to measure progress on over $50 \%$ of the plans' objectives were unavailable or insufficiently robust to report in the progress review. Commitments to address these issues in the future, such as the use of semi-structured interviews, are deployed by the government to assuage concern about data gaps (DEFRA 2014). No explanation is given, however, as to why these strategies were not implemented during this review when data gaps became apparent.

\section{Developing progressive MSP governmentalities}

The issues to be addressed through MSP are not incontrovertible truths but are, rather, socially constructed problems created and propounded through specific and powerful governmentalities. As can be seen in our case study, there are complex relationships between the three core components of governmentalities, and it is important to analyse the genealogy of governmentalities. 
Including a time/space dimension as part of the evaluation allows us to understand how a governmentality changes (Lemke 2019), how core components become altered, and where and how difference can be inserted into MSP processes. Although problematisations are creative processes of framing an issue as both a problem and as a governance object (Hutter et al. 2014), our findings also illustrate their dissembling and duplicitous nature. While a range of issues were problematised in the early planning phase, only issues related to the neoliberalisation of marine management were championed by the government throughout the entirety of the process. It is recognised in the literature that governmental technologies may need to become rationalised as their utility to a governmentality becomes apparent (Dean 1999; Rap and Wester 2017). Within our case study, however, technologies from the early planning phase become problematised in the later phases. In this way, the government uses the cyclical and iterative nature of planning to problematise progressive technologies, such as meaningful stakeholder participation, that were mobilised to gain early support but needed to be discarded to clear a pathway for narrow and neoliberal governance reforms.

As will be discussed below, it is clear from our analysis that the governmentality being advanced by the government takes on different guises as it moves through the planning phases, shedding progressive elements the closer it gets to actualisation in the operational phase. As the governmentality progresses through time/space, the problematisations, rationalities and technologies utilised by the government change from those focused on progressive reform, to narrowly focus on the instigation of a neoliberal form of MSP. The issues to be addressed by the government through MSP shift from being problematised as being about reforming the state's approach to marine governance so that it benefits all, to focus on reducing the "bureaucratic burden" on industry. This goal is advanced despite the government acknowledging the severe environmental and spatial constraints on increasing development. The goal of neoliberalising marine governance cannot, however, be advanced as the sole focus of MSP, particularly not during the early phases wherein stakeholder and broader political buy-in are necessary. Instead, during the normative phase, MSP is framed as a radical break with the previous governance regime and a process which will ultimately instigate good governance in the marine environment and enhance coastal community well-being. The final governmentality that emerges from our analysis, however, illustrates that the ultimate, and perhaps only, goal is to instigate a pro-development, neoliberal form of MSP that promotes further resource exploitation through the reduction of the regulatory burden on marine industries. Whether instigating a neoliberal form of MSP is the original aim of the architects of English MSP may be debatable. As the process moves through each planning phase, however, it becomes the overriding governmentality actioned by the government.
Governmentalities are not, however, static or unchangeable, and by understanding how they emerge we can explore how they can be made different. Acknowledging the conditional and malleable nature of governmentalities is central to Foucault's disruptive political vision, "because it highlights the extent to which things could have been and thus can become different" (Hutchinson and O'Malley 2019, p.71). Identifying when and where in the planning process to insert difference is critical to efforts to reimagine MSP (Boucquey et al. 2016; Garland et al. 2019) and to developing progressive governmentalities (Fletcher 2010). It is important, therefore, to understand how to access each phase and how each one presents different opportunities for governmentalities to be resisted or reformed.

Drawing on Mouffe (2018), we argue that a political frontier must be established during the normative phase of MSP processes. This is critical to any attempt to reimagine MSP. During the normative phase, governmentalities must seek to win broad support so that they may progress to the next phase without major alterations. As can be seen from our case study, governmentalities do this by including high-level, progressive problematisation of the status quo, that appear to be rationalised in apolitical terms and outline enlightened technologies that will deliver a programme of radical change. A commitment to add detail and substance to these elements during subsequent phases is too often used to co-opt those seeking to radically reform inequitable regimes. Ultimately, the iterative nature of planning is used to push the development of these progressive elements into the next cycle of the planning process. Although planning is an iterative process, it rarely returns to the normative or strategic phases and tends to get stuck in a path-dependent loop between the operational and monitoring phases. For example, the commitment by the government to collect new data after plan implementation means that new knowledge may be incorporated into the next iteration of the plan, but it is unlikely that this new data will instigate a return to the normative and strategic phases. Instead, the utility of any new data will be incorporated in a path-dependent manner into the next version of the plans. Inserting difference must, therefore, be instigated during the normative phase.

Developing a political frontier during this phase must focus on how to resist the slide of MSP into the post-political trap of tokenistic participation (Flannery et al. 2018) and the technocratic-managerialism forms of governance dominated by mapping, GIS, and data portals (Smith and Brennan 2012; Boucquey et al. 2016; Trouillet et al. 2019). Instead, this frontier must serve as a means of inserting or applying counter-hegemonic objectives or alternative imaginaries (Walsh 2018) and developing clear pathways to societal and environmental impact, to be activated in subsequent planning phases. To be successful, this political frontier must politicise the normative phase of MSP (Clarke and Flannery 
2019) and must result in the discussion and popularisation of progressive alternatives (Mouffe 2018) to neoliberal MSP.

In the English MSP process, a clear pathway to impact could have been developed for the objective of enhanced coastal well-being. This could have provided detail on what enhanced well-being would look like, how it would be measured and, most critically, the strategies and measurable actions that could be implemented to achieve it. In contemporary planning practices, these details are to be added as an initiative progresses through the planning phases, providing opportunities for progressive goals to be problematised out of the process. A political frontier in the normative phase must, therefore, provide resistance against efforts to move onto the subsequent phases until clear pathways for achieving progressive goals have been developed. We must fight the notion that details can be added during subsequent phases and make later phases about implementing clearly defined, progressive pathways, which would limit opportunities for the erosion of transformative goals.

The strategic phase is often inaccessible to the public and is dominated by policy entrepreneurs, civil servants and other powerful actors with the capacity to shape government actions. We must develop the capacity to give voice to those excluded from this phase. Researchers and non-governmental organisations (NGOs) have a particular role to play in ensuring that progressive elements of MSP (e.g. participation, well-being, robust evidence) are not problematised out of MSP processes and that they resist the need for planning to happen quickly. Speed and the need for momentum are requirements of capital (Harvey 1985) and are often used by governments to justify hasty decision-making, which tends to reproduce neoliberal hegemonies. During the strategic phase, researchers, NGOs and others must act as advocates (Saunders et al. 2019) for those unable to access decision-making spheres and focus on ensuring that technologies to deliver progressive change are enhanced rather than eroded. In the English MSP example, advocate planners, researchers and others could have been mobilised to resist government efforts to implement tokenistic stakeholder engagement processes and to make the process more meaningful to marginal groups. The value of participation must be reviewed and enhanced throughout the MSP process (Quesada-Silva et al. 2019).

There is often limited scope for drastic programme change during the operational phase. This is the point in the process where governmentalities meet reality. Although it is often the phase which appears most open, participation during this phase is often tokenistic, with very little change being achieved in terms of policies and objectives. Paradoxically, this is often the phase where non-elite stakeholders become most interested in planning processes, as it becomes clearer to them how they will be impacted by plans (Flannery et al. 2018). Non-elite engagement at this point tends to elongate the planning process but rarely changes its overall direction. During this phase, difference can be inserted by challenging attempts to undertake planning with insufficient data, and also including data from marginalised groups in the process. For example, local ecological and spatial knowledge can be used by activists to give voice to non-elite stakeholders (Murray et al. 2008; St. Martin and Olson 2017). Government efforts to move progressive MSP elements into the next iteration of the process must be resisted, avoiding negative pathdependent objectives being replicated across iterations.

The monitoring phase is often very closed and usually only accessible to civil servants, government party apparatchiks and key policy influencers. Research that monitors MSP capacity to deliver progressive change must be developed by those not privileged with access to, or co-opted into, formal monitoring processes. Researchers developing broader approaches to monitoring should also focus on assessing the unintended impacts of plans and finding pathways for their assessments to be incorporated into the next iteration of planning processes. Given the desire to accelerate MSP globally (see, for example, the joint UNSECO EU MSP Global programme), research on the impacts of MSP in early adopting countries must be undertaken quickly by researchers, and alternative mechanisms for realising progressive societal and environmental outcomes should be developed in conjunction with local actors in countries that are just beginning their MSP processes.

MSP contains vast transformative potential, including the possibility of shifting from a sectoral to a place-based approach and the capacity to reduce the democratic deficit in marine governance. Neoliberal and conservative governmentalities have, however, steered it towards preserving the status quo and narrowly achieving economic objectives. Understanding how these governmentalities develop and recognising opportunities in planning processes where they can be resisted, is critically important to developing a more radical form of MSP. This understanding must be developed quickly by those interested in advancing progressive and radical forms of MSP and implemented before it loses all credibility as a transformative process.

Acknowledgements Wesley Flannery's contribution to this paper was partly funded by the FAIRCoast project which is funded by the Research Council of Norway, project number 294799.

Open Access This article is licensed under a Creative Commons Attribution 4.0 International License, which permits use, sharing, adaptation, distribution and reproduction in any medium or format, as long as you give appropriate credit to the original author(s) and the source, provide a link to the Creative Commons licence, and indicate if changes were made. The images or other third party material in this article are included in the article's Creative Commons licence, unless indicated otherwise in a credit line to the material. If material is not included in the article's Creative Commons licence and your intended use is not permitted by statutory regulation or exceeds the permitted use, you will need to obtain 
permission directly from the copyright holder. To view a copy of this licence, visit http://creativecommons.org/licenses/by/4.0/.

\section{References}

Aschenbrenner, M., and G.M. Winder. 2019. Planning for a sustainable marine future? Marine spatial planning in the German exclusive economic zone of the North Sea. Applied Geography 110: 102050.

Barbesgaard, M. 2018. Blue growth: Savior or ocean grabbing? Journal of Peasant Studies 45 (1): 130-149.

Bennett, N.J., J. Blythe, A.M. Cisneros-Montemayor, G.G. Singh, and U.R. Sumaila. 2019. Just transformations to sustainability. Sustainability 11 (14): 3881.

Benyon, R., 2010. Richard Benyon speech - Charting Progress 2 launch. 21st July. Available at: https://www.gov.uk/government/speeches/ richard-benyon-speech-charting-progress-2-launch. Accessed 25 Aug 2018.

Blythe, J., J. Silver, L. Evans, D. Armitage, N.J. Bennett, M.L. Moore, T.H. Morrison, and K. Brown. 2018. The dark side of transformation: Latent risks in contemporary sustainability discourse. Antipode 50 (5): 1206-1223.

Boucquey, N., L. Fairbanks, K.S. Martin, L.M. Campbell, and B. McCay. 2016. The ontological politics of marine spatial planning: Assembling the ocean and shaping the capacities of 'community' and 'environment'. Geoforum 75: 1-11.

Boucquey, N., St Martin, K., Fairbanks, L., Campbell, L. M., \& Wise, S. (2019). Ocean data portals: Performing a new infrastructure for ocean governance. Environment and Planning D: Society and Space 37 (3): 484-503

Bresnihan, P. 2019. Revisiting neoliberalism in the oceans: Governmentality and the biopolitics of 'improvement' in the Irish and European fisheries. Environment and Planning A: Economy and Space 51 (1): 156-177.

Choi, Y.R. 2017. The Blue Economy as governmentality and the making of new spatial rationalities. Dialogues in Human Geography 7 (1): $37-41$.

Clarke, J. and Flannery, W., 2020. The post-political nature of marine spatial planning and modalities for its re-politicisation. Journal of Environmental Policy \& Planning 22 (2): 170-183.

Cohen, P., E.H. Allison, N.L. Andrew, J.E. Cinner, L.S. Evans, M. Fabinyi, L.R. Garces, S.J. Hall, C.C. Hicks, T.P. Hughes, and S. Jentoft. 2019. Securing a just space for small-scale fisheries in the blue economy. Frontiers in Marine Science 6: 171.

Dean, M. 1999. Governmentality: Power and rule in modern society. London: Sage.

DEFRA, 2010. Radical new way of managing our seas published today. $21^{\text {st }}$ July 2010. Available at: https://www.gov.uk/government/news/ radical-new-way-of-managing-our-seas-published-today. Accessed 25 Aug 2019.

DEFRA. 2011. UK Marine Policy Statement. London: The Stationery Office Limited.

DEFRA. 2014. East Inshore and East Offshore Marine Plans. London: DEFRA.

DEFRA. 2017. Three-year report on the East Marine Plans. London: DEFRA.

Díaz, S., U. Pascual, M. Stenseke, B. Martín-López, R.T. Watson, Z. Molnár, R. Hill, K.M. Chan, I.A. Baste, K.A. Brauman, and S. Polasky. 2018. Assessing nature's contributions to people. Science 359 (6373): 270-272.

Douvere, F. 2008. The importance of marine spatial planning in advancing ecosystem-based sea use management. Marine Policy 32 (5): $762-771$.

Dreyfus, H.L., and P. Rabinow. 2014. Michel Foucault: Beyond structuralism and hermeneutics. Routledge.
Dupont, D., and F. Pearce. 2001. Foucault contra Foucault: Rereading the 'Governmentality' papers. Theoretical Criminology 5: 123-158.

Ehler, C. and Douvere, F. (2009). Marine Spatial Planning: a step-bystep approach toward ecosystem-based management. (No. Intergovernmental Oceanographic Commission and Man and the Biosphere Programme. IOC Manual and Guides No. 53, ICAM Dossier No. 6). Paris: UNESCO.

Fairbanks, L. 2019. Policy mobilities and the sociomateriality of US offshore aquaculture governance. Environment and Planning $C$ : Politics and Space 37 (5): 849-867.

Fairbanks, L., L.M. Campbell, N. Boucquey, and K. St. Martin. 2018. Assembling enclosure: Reading marine spatial planning for alternatives. Annals of the American Association of Geographers 108 (1): 144-161.

Fairbanks, L., N. Boucquey, L.M. Campbell, and S. Wise. 2019. Remaking oceans governance: Critical perspectives on marine spatial planning. Environment and Society 10 (1): 122-140.

Flannery, W., 2011. Marine spatial planning from an irish perspective: Towards best practice in integrated maritime governance (Doctoral dissertation). National University of Ireland, Galway.

Flannery, W., Ellis, G., Nursey-Bray, M., van Tatenhove, J. P., ... \& Jentoft, S. (2016). Exploring the winners and losers of marine environmental governance/Marine spatial planning: Cui bono?/"More than fishy business": epistemology, integration and conflict in marine spatial planning/Marine spatial planning: power and scaping/ Surely not all planning is evil?/Marine spatial planning: a Canadian perspective/Maritime spatial planning-"ad utilitatem omnium"/ Marine spatial planning:"it is better to be on the train than being hit by it"/Reflections from the perspective of recreational anglers .... Planning Theory \& Practice, 17(1), 121-151.

Flannery, W., N. Healy, and M. Luna. 2018. Exclusion and nonparticipation in marine spatial planning. Marine Policy 88: 32-40.

Flannery, W., J. Clarke, and B. McAteer. 2019. Politics and power in marine spatial planning. In Maritime Spatial Planning, ed. J. Zaucha and K. Gee, 201-217. London: Palgrave Macmillan.

Fletcher, R. 2010. Neoliberal environmentality: Towards a poststructuralist political ecology of the conservation debate. Conservation and Society 8 (3): 171-181. https://doi.org/10.4103/ 0972-4923.73806.

Flyvberg, B. 1998. Rationality and power. Chicago: University of Chicago Press.

Flyvbjerg, B., and T. Richardson. 2002. Planning and Foucault: In search of the dark side of planning theory. In Planning futures: New directions for planning theory, ed. P. Allmendinger and M. TewdwrJones, 44-62. London and New York: Routledge.

Foley, M.M., B.S. Halpern, F. Micheli, M.H. Armsby, M.R. Caldwell, C.M. Crain, E. Prahler, N. Rohr, D. Sivas, M.W. Beck, and M.H. Carr. 2010. Guiding ecological principles for marine spatial planning. Marine Policy 34 (5): 955-966.

Foley, P., D.A. Okyere, and C. Mather. 2018. Alternative environmentalities: Recasting the assessment of Canada's first Marine Stewardship Council-certified fishery in social terms. Ecology and Society 23 (3).

Foucault, M. 1982. The subject and power. In Michel Foucault. Beyond structuralism and hermeneutics, ed. H. Dreyfus and P. Rabinow, 208-226. Chicago: University of Chicago Press.

Foucault, M. 1991a. Questions of method. In The Foucault effect: Studies in governmentality, ed. G. Burchell, C. Gordon, and P. Miller, 7386. London: Harvester/Wheatsheaf.

Foucault, M. 1991b. Governmentality. In The Foucault effect: Studies in governmentality, ed. G. Burchell, C. Gordon, and P. Miller, 87-104. London: Harvester/Wheatsheaf

Foucault, M. 2003. The subject and power. In The essential Foucault: Selections from essential works of Foucault, ed. P. Rabinow and N. Rose, 1954-1984. London: The New Press. 
Foucault, M. 2007. Security, territory, population. Lectures at the Collège de France 1977-78. New York: Palgrave Macmillan.

Garland, M., S. Axon, M. Graziano, J. Morrissey, and C.P. Heidkamp. 2019. The blue economy: Identifying geographic concepts and sensitivities. Geography Compass 13 (7): e12445.

Gissi, E., S. Fraschetti, and F. Micheli. 2019. Incorporating change in marine spatial planning: A review. Environmental Science \& Policy 92: 191-200.

Hadjimichael, M. 2018. A call for a blue degrowth: Unravelling the European Union's fisheries and maritime policies. Marine Policy 94: $158-164$.

Hannah, M.G. 2000. Governmentality and the mastery of territory in nineteenth-century America. Vol. 32. Cambridge: Cambridge University Press.

Harvey, D. 1985. The urbanization of capital. Baltimore: Johns Hopkins University Press.

Hillier, J. 2015. Performances and performativities of resilience. In Evolutionary governance theory, ed. R. Beunen, K. van Assche, and M. Duineveld, 167-183. Heidelberg: Springer.

Hutchinson, S., and P. O'Malley. 2019. Discipline and Governmentality. In The handbook of social control, ed. M. Deflen, 63-75. New Jersey: Wiley Blackwell.

Hutter, G., M. Leibenath, and A. Mattissek. 2014. Governing through resilience? Exploring flood protection in Dresden, Germany. Social Science 3: 272-287.

Huxley, M. 2008. Space and government: Governmentality and geography. Geography Compass 2 (5): 1635-1658.

Jay, S., W. Flannery, J. Vince, W.-H. Liu, J.G. Xue, M. Matczak, et al. 2013. International progress in marine spatial planning. Ocean Yearbook Online 27: 171-212.

Johnsen, J.P. 2017. Creating political spaces at sea-governmentalisation and governability in Norwegian fisheries. Maritime Studies 16 (1): 18.

Jones, P.J., L.M. Lieberknecht, and W. Qiu. 2016. Marine spatial planning in reality: Introduction to case studies and discussion of findings. Marine Policy 71: 256-264.

Kelly, C., G. Ellis, and W. Flannery. 2018. Conceptualising change in marine governance: Learning from transition management. Marine Policy 95: 24-35.

Kelly, C., G. Ellis, and W. Flannery. 2019. Unravelling persistent problems to transformative marine governance. Frontiers in Marine Science 6: 213

Lemke, T. 2001. 'The birth of bio-politics': Michel Foucault's lecture at the Collège de France on neo-liberal governmentality. Economies et Societes 30 (2): 190-207.

Lemke, T. 2002. Foucault, governmentality, and critique. Rethinking Marxism 14 (3): 49-64.

Lemke, T. 2019. A critique of political reason: Foucault's analysis of modern governmentality. New York: Verso.

McKee, K. 2009. Post-Foucauldian governmentality: What does it offer critical social policy analysis? Critical Social Policy 29 (3): 465486.

Merlingen, M. 2011. From governance to governmentality in CSDP: Towards a Foucauldian research agenda. Journal of Common Market Studies 49: 149-169.

MMO, 2013. Government takes action to cut red tape for coastal projects and investments. 26th February 2013. Available at: https://www. gov.uk/government/news/government-takes-action-to-cut-red-tapefor-coastal-projects-and-investments. Accessed 25 Aug 2019.

MMO, 2014. East inshore and East Offshore marine plan areas: Evidence and issues report overview report 2012.

MMO, 2015. East Inshore and Offshore marine plan areas: Statement of public participation, Revised March 2015.

Moon, J., W. Flannery, and A. Revez. 2017. Discourse and practice of participatory flood risk management in Belfast, UK. Land Use Policy 63: 408-417.
Mouffe, C. 2018. For a left populism. London: Verso.

Murphy, E., and L. Fox-Rogers. 2015. Perceptions of the common good in planning. Cities 42: 231-241.

Murray, G., B. Neis, C.T. Palmer, and D.C. Schneider. 2008. Mapping cod: Fisheries science, fish harvesters' ecological knowledge and cod migrations in the Northern Gulf of St. Lawrence. Human Ecology 36 (4): 581-598.

O'Malley, P., L. Weir, and C. Shearing. 1997. Governmentality, criticism, politics. Economies et Societes 26: 501-517.

Peters, K., and P. Steinberg. 2019. The ocean in excess: Towards a morethan-wet ontology. Dialogues in Human Geography 9 (3): 293-307.

Quesada-Silva, M., A. Iglesias-Campos, A. Turra, and J.L. Suárez-de Vivero. 2019. Stakeholder Participation Assessment Framework (SPAF): A theory-based strategy to plan and evaluate marine spatial planning participatory processes. Marine Policy 108: 103619.

Rap, E., and P. Wester. 2017. Governing the water user: Experiences from Mexico. Journal of Environmental Policy \& Planning 19 (3): 293307.

Ritchie, H., and G. Ellis. 2010. 'A system that works for the sea'? Exploring stakeholder engagement in marine spatial planning. Journal of Environmental Planning and Management 53 (6): $701-$ 723.

Robertson, M. 2012. Measurement and alienation: Making a world of ecosystem services. Transactions of the Institute of British Geographers 37 (3): 386-401.

Rose, N.S. 1996. Inventing ourselves. Cambridge: Cambridge University Press.

Rose, N.S., and P. Miller. 1992. Political power beyond the state: Problematics of government. The British Journal of Sociology 43 (2): 173-205.

Rutherford, S. 2007. Green governmentality: Insights and opportunities in the study of nature's rule. Progress in Human Geography 31 (3): 291-307.

Sander, G. 2018. Ecosystem-based management in Canada and Norway: The importance of political leadership and effective decisionmaking for implementation. Ocean and Coastal Management 163: 485-497.

Satizábal, P., W.H. Dressler, M. Fabinyi, and M.D. Pido. 2020. Blue economy discourses and practices: Reconfiguring ocean spaces in the Philippines. Maritime Studies 2020. https://doi.org/10.1007/ s40152-020-00168-0.

Saunders, F.P., M. Gilek, and R. Tafon. 2019. Adding people to the sea: Conceptualizing social sustainability in maritime spatial planning. In Maritime Spatial Planning, ed. J. Zaucha and K. Gee, 175-200. London: Palgrave Macmillan.

Schutter, M.S., and C.C. Hicks. 2019. Networking the Blue Economy in Seychelles: Pioneers, resistance, and the power of influence. Journal of Political Ecology 26 (1): 425-447.

Smith, L.G. 1982. Mechanisms for public participation at a normative planning level in Canada. Canadian Public Policy/Analyse de Politiques 8: 561-572.

Smith, G. 2018. Good governance and the role of the public in Scotland's marine spatial planning system. Marine Policy 94: 1-9.

Smith, G., and R.E. Brennan. 2012. Losing our way with mapping: Thinking critically about marine spatial planning in Scotland. Ocean and Coastal Management 69: 210-216.

Smith, G., and S. Jentoft. 2017. Marine spatial planning in Scotland. Levelling the playing field? Marine Policy 84: 33-41.

St. Martin, K., and M. Hall-Arber. 2008. The missing layer: Geo-technologies, communities, and implications for marine spatial planning. Marine Policy 32 (5): 779-786.

St. Martin, K., and J. Olson. 2017. Creating space for community in marine conservation and management: Mapping 'communities at sea'. In Conservation in the Anthropocene Ocean, ed. P. Levin and M. Poe, 123-141. Elsevier. 
Stafford, R., and P.J. Jones. 2019. Viewpoint-Ocean plastic pollution: A convenient but distracting truth? Marine Policy 103: 187-191.

Stefansson, G., A.E. Punt, J. Ruiz, I. van Putten, S. Agnarsson, and A.K. Daníelsdóttir. 2019. Implementing the ecosystem approach to fisheries management. Fisheries Research 216: 174-176.

Stephan, B., C. Methmann, and D. Rothe. 2013. Third side of the coin: Hegemony and governmentality in global climate politics, 59-76. New York: Cambridge University Press.

Tafon, R.V. 2018. Taking power to sea: Towards a post-structuralist discourse theoretical critique of marine spatial planning. Environment and Planning C: Politics and Space 36 (2): 258-273.

Tafon, R.V. 2019. Small-scale fishers as allies or opponents? Unlocking looming tensions and potential exclusions in Poland's marine spatial planning. Journal of Environmental Policy \& Planning: 1-12.

Tafon, R., Howarth, D., \& Griggs, S. (2018). The politics of Estonia's offshore wind energy programme: Discourse, power and marine spatial planning. Environment and Planning C: Politics and Space, 2399654418778037

Taylor, D. 2011. Michel Foucault: Key concepts. Durham: Acumen.

Toonen, H.M., and J.P. van Tatenhove. 2013. Marine scaping: The structuring of marine practices. Ocean and Coastal Management 75: 4352.
Trouillet, B. 2019. Aligning with dominant interests: The role played by geo-technologies in the place given to fisheries in marine spatial planning. Geoforum 107: 54-65.

Trouillet, B., L. Bellanger-Husi, A. El Ghaziri, C. Lamberts, E. Plissonneau, and N. Rollo. 2019. More than maps: Providing an alternative for fisheries and fishers in marine spatial planning. Ocean and Coastal Management 173: 90-103.

Walsh, C. 2018. Metageographies of coastal management: Negotiating spaces of nature and culture at the Wadden Sea. Area 50 (2): 177185.

Wang, X., C. Hawkins, and E. Berman. 2014. Financing sustainability and stakeholder engagement: Evidence from US cities. Urban Affairs Review 50 (6): 806-834.

White, C., B.S. Halpern, and C.V. Kappel. 2012. Ecosystem service tradeoff analysis reveals the value of marine spatial planning for multiple ocean uses. Proceedings of the National Academy of Sciences 109 (12): 4696-4701.

Publisher's note Springer Nature remains neutral with regard to jurisdictional claims in published maps and institutional affiliations. 